\title{
Mucoprotein-containing histiocytes (muciphages) in the rectum
}

\author{
J. G. AZZOPARDI AND D. J. EVANS \\ From the Department of Morbid Anatomy, Postgraduate Medical School, London
}

SYNOPSIS Mucoprotein-containing macrophages (muciphages) are a common finding in routineg rectal biopsies, occurring in about $50 \%$ of cases. No correlation was found between their presences and the sex, age, and disease of the patient. They must be distinguished from the cells of Whipple's $\vec{\bullet}$ disease and from lipofuscin-containing macrophages. The origin of the mucoprotein is discussedi and rectal epithelial mucin is considered a possible source.

In the lamina propria of the large intestine various cell types may be seen which are positively stained by the periodic-acid-Schiff (P.A.S.) method. These include mast cells, the macrophages of melanosis coli (Pearse, 1960), of Whipple's disease (Fleming, Yardley and Hendrix, 1962), of ceroid-like histiocytosis (Fisher and Hellstrom, 1964), and of a colonic histiocytosis of children (Rowlands and Landing, 1960).

In common with certain other investigators (Arapakis and Tribe, 1963; Hourihane, 1966) we have observed a group of positively staining cells, which we shall refer to as 'muciphages'. Because of the problems of differentiating these from cells seen in other conditions we have studied their staining reactions and attempted to define points of differentiation from Whipple's disease and from other entities. We have also attempted to obtain a crude estimate of their frequency in surgical material.

\section{MATERIALS AND METHODS}

Ten rectal biopsies containing the muciphages were selected from the routine surgical material. In one instance formalin-fixed wet material was available and was used for frozen section as indicated.

Two blocks of colon from cases of melanosis coli, a mesenteric lymph node from a case of Whipple's disease, and a small intestinal biopsy from a case of Whipple's disease were used for comparison. A rectal biopsy from the latter case was also studied.

For estimates of frequency 60 rectal biopsies, blocks from 28 colectomy and from 20 appendicectomy specimens were studied by haemalum and eosin, P.A.S., Alcian green, and mucicarmine stains. Each section was sub-

'Present address: Department of Pathology, London Hospital, Whitechapel, London, E.1.

Received for publication 17 January 1966. jectively classified as containing no cells $(0)$, occasionak $(+)$, moderate numbers $(++)$, or many $(+++)$ cells.

All the tissues, except where otherwise stated, werefixed in formol-mercury.

For electron microscopy five rectal biopsies were obtained from volunteers at the time of injection of piles. The specimen was immediately divided into two. Ones portion was fixed in formalin and processed routinely. The other portion (average volume 1-2 c.mm.) was placeda immediately into glutaraldehyde buffered with Sorensen'sक phosphate buffer to $p \mathrm{H}$ 6.98. After 24 hours it was transferred to phosphate buffer $\left(p \mathrm{H} \mathrm{6.98)}\right.$ and kept at $4^{\circ} \mathrm{C} . \overrightarrow{0}$ until the paraffin sections had been studied. The relevant 3 blocks were then transferred to osmium tetroxide for? one hour at $4^{\circ} \mathrm{C}$., passed through distilled water andọ. alcohol, and embedded in Araldite. Sections were cut on an N K B ultratome at $500 \AA$ (units) and stained with leadô citrate or uranyl acetate. Paraffin sections on the five biopsies showed that two of them contained muciphages 3 One of these also contained considerable quantities of as ZN-positive, P.A.S.-positive, yellow-brown pigment con-₹ sidered to be lipofuscin. Both specimens were studied byo electron microscopy.

For enzyme studies, rectal biopsies were obtained fron four volunteers at the time of injection of piles. Frozen sections, at $8 \mu$, were cut from the specimens. Muciphages were indentified in one of the specimens.

\section{RESULTS}

The cells vary considerably in size and shape (Fig. 1) They may be round, oval, elongated, or irregular $\bar{D}$ Usually they are large $(40 \mu \text { or more in diameter })^{f}$ but they may be as little as $10 \mu$ in diameter. The cello border is indistinct. With haemalum and eosin the cytoplasm is amphophilic, usually staining bluist grey. It contains multiple vacuoles which vary ing size but are usually only about 1 to $2 \mu$ diameter. Iro routine sections the vacuoles appear somewhat $\mathrm{re}_{\overparen{8}}$ 


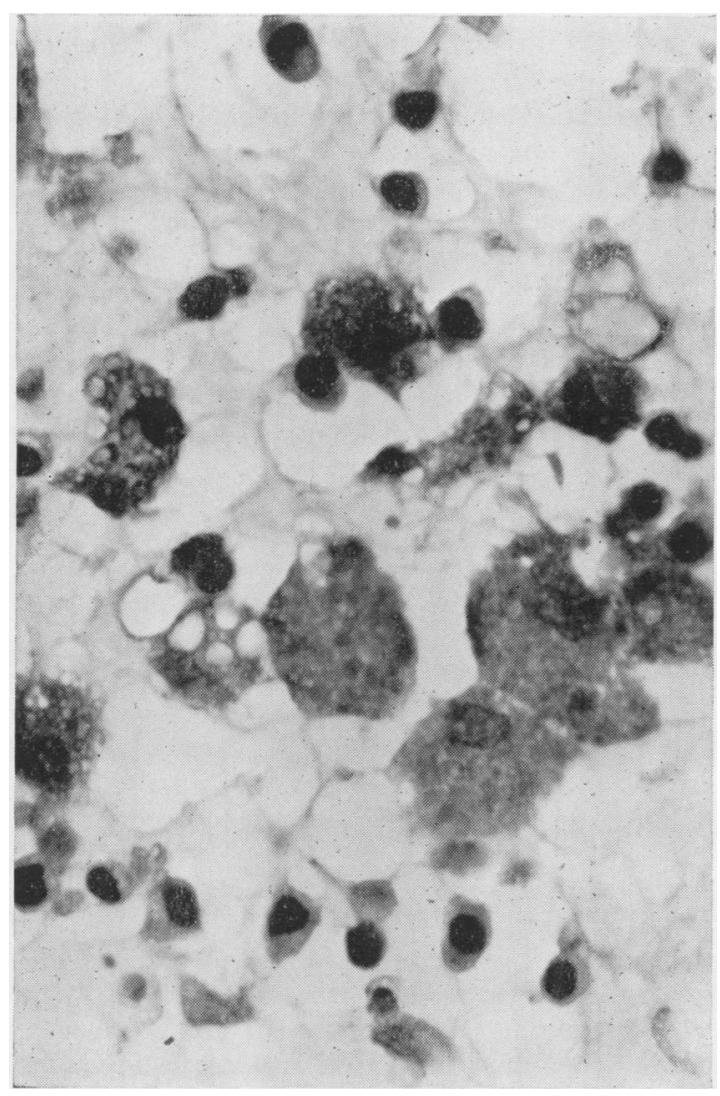

FIG. 1. A clump of muciphages of variable shape. The vacuoles are coloured with mucicarmine. Mucicarmine $\times 970$.

fractile but in thin sections the vacuolation gives the cells a foamy appearance. The cells are found anywhere in the mucosa and occasionally in the muscularis mucosae, scattered singly or in groups. The nuclei are usually ovoid, quite frequently eccentric and relatively small. In general they have the characteristics of histiocyte nuclei.

The incidence of the cells is set out in Table I. The proportion of positives in rectal biopsies is seen to be in the region of $50 \%$. In the colon the incidence is only about $18 \%$ in a study of larger areas of tissue. This incidence is significantly different $(P=0.01)$. In the appendix typical muciphages were not seen.

TABLE I

INCIDENCE OF MUCIPHAGES AT VARIOUS SITES

\begin{tabular}{lccccc} 
Organ & \multicolumn{2}{c}{ Number } & of Cases in & Each Category & Total Cases \\
\hline & 0 & + & ++ & +++ & \\
Appendix & 20 & 0 & 0 & 0 & 20 \\
Colon & 23 & 2 & 2 & 1 & 28 \\
Rectum & 29 & 9 & 13 & 9 & 60
\end{tabular}

A further analysis was performed to determine whether the incidence of the cells in the rectum was correlated with sex, age, history of diarrhoea, clinical history of proctocolitis, or pathological diagnosis of proctitis. The results are set out in Tables II and III.

TABLE II

INCIDENCE OF MUCIPHAGES ACCORDING TO DISEASE STATE

\begin{tabular}{ll}
$\begin{array}{l}\text { Muciphages } \\
\text { Present }\end{array}$ & $\begin{array}{l}\text { Muciphages } \\
\text { Absent }\end{array}$ \\
\hline
\end{tabular}

\begin{tabular}{lcc}
\hline Cases with no diarrhoea & 17 & 16 \\
$\begin{array}{l}\text { All cases with diarrhoea } \\
\text { Cases clinically diagnosed as ulcerative }\end{array}$ & 14 & 13 \\
$\begin{array}{l}\text { colitis } \\
\begin{array}{l}\text { pases with pathological confirmation of } \\
\text { proctitis }\end{array}\end{array}$ & 8 & 8 \\
\end{tabular}

TABLE III

INCIDENCE OF MUCIPHAGES ACCORDING TO AGE AND SEX

\begin{tabular}{ll}
$\begin{array}{l}\text { Muciphages } \\
\text { Present }\end{array}$ & $\begin{array}{l}\text { Muciphages } \\
\text { Absent }\end{array}$ \\
\hline
\end{tabular}

\begin{tabular}{lrr}
\hline Sex & & \\
Male & 16 & 16 \\
Female & 15 & 13 \\
Age $(y r)$. & & \\
$0-10$ & 0 & 3 \\
$11-30$ & 9 & 5 \\
$31-50$ & 10 & 6 \\
$51-70$ & 9 & 11 \\
$70+$ & 2 & 3
\end{tabular}

From these it can be seen that there is no sex predilection, and that the cells occur in cases with or without diarrhoea, clinical colitis, or pathological evidence of proctitis. They were also present in all but the youngest age group. By the courtesy of Dr. A. Claireaux we were able to study 10 rectal biopsies taken from children ranging in age from 17 days to 5 years and in two of these (aged 20 and 33 months) we found muciphages. The numbers are small and, though there is a suggestion of a lower incidence in this age group, this is not statistically significant.

The staining properties of the cells were further investigated. The results are set out in Table IV. We found the cells not to be acid-fast, and oil red $O$ and Sudan black failed to show the presence of lipids.

In mercury-fixed material only weak metachromasia is demonstrable but in formalin-fixed frozen sections alcohol-stable metachromasia is present. Positive reactions are obtained with P.A.S., diastase P.A.S., mucicarmine, Hale's iron, Alcian green, and Gomori's aldehyde fuchsin.

We conclude from these findings that one or more mucoproteins is present and that there are both neutral and acidic mucoprotein groups. The enzyme studies show the pattern expected in macrophages.

In the rectal biopsy from the patient with Whipple's disease both Whipple cells and macro- 
TABLE IV

STAINING PROPERTIES OF THE CELLS

\begin{tabular}{|c|c|c|c|}
\hline Stain & Muciphages & $\begin{array}{l}\text { Whipple's } \\
\text { Disease }\end{array}$ & $\begin{array}{l}\text { Melanosis } \\
\text { Coli }\end{array}$ \\
\hline $\left.\begin{array}{l}\text { P.A.S. } \\
\text { Diastase P.A.S. } \\
\text { Mucicarmine } \\
\text { Alcian green } \\
\text { Alcian blue }\end{array}\right\}$ & $\begin{array}{l}\text { Positive } \\
\text { Positive } \\
\text { Positive } \\
\text { Positive }\end{array}$ & $\begin{array}{l}\text { Positive } \\
\text { Positive } \\
\text { Negative } \\
\text { Negative }\end{array}$ & $\begin{array}{l}\text { Positive } \\
\text { Positive } \\
\text { Negative } \\
\text { Negative }\end{array}$ \\
\hline $\begin{array}{l}\text { Gomori's aldehyde fuchsin } \\
\text { Hale's dialysed iron } \\
\text { Toluidine blue }\end{array}$ & $\begin{array}{l}\text { Positive } \\
\text { Positive } \\
\text { Weak } \\
\quad \text { positive }\end{array}$ & $\begin{array}{l}\text { Negative } \\
\text { Positive } \\
\text { Negative }\end{array}$ & $\begin{array}{l}\text { Negative } \\
\text { Negative } \\
\text { Negative }\end{array}$ \\
\hline $\left.\begin{array}{l}\text { Toluidine blue (frozen section) } \\
\text { Ferric ferricyanide } \\
\text { Masson-Fontana }\end{array}\right\}$ & $\begin{array}{l}\text { Positive } \\
\text { Negative }\end{array}$ & $\begin{array}{l}\text { Not done } \\
\text { Negative }\end{array}$ & $\begin{array}{l}\text { Not done } \\
\text { Positive }\end{array}$ \\
\hline $\begin{array}{l}\text { Sudan black B } \\
\text { Sudan black (frozen section) } \\
\text { Oil red O (frozen section) } \\
\text { Luxol fast blue } \\
\text { Long Ziehl-Neelsen } \\
\text { Long Giemsa }\end{array}$ & $\begin{array}{l}\text { Negative } \\
\text { Negative } \\
\text { Negative } \\
\text { Negative } \\
\text { Negative } \\
\text { Blue }\end{array}$ & $\begin{array}{l}\text { Negative } \\
\text { Not done } \\
\text { Not done } \\
\text { Negative } \\
\text { Negative } \\
\text { Pale Blue }\end{array}$ & $\begin{array}{l}\text { Positive } \\
\text { Not done } \\
\text { Not done } \\
\text { Negative } \\
\text { Positive } \\
\text { Green }\end{array}$ \\
\hline Perl & Negative & $\begin{array}{l}\text { Positive- } \\
\text { lymph } \\
\text { node } \\
\text { Negative- } \\
\text { small } \\
\text { intestine }\end{array}$ & Negative \\
\hline Autofluorescence & $\begin{array}{l}\text { Weak } \\
\text { positive }\end{array}$ & Not done & Positive \\
\hline $\begin{array}{l}\text { Thioflavin-T } \\
\text { Acid phosphatase } \\
\text { Alkaline phosphatase } \\
\text { Non-specific esterase }\end{array}$ & $\begin{array}{l}\text { Positive } \\
\text { Positive } \\
\text { Negative } \\
\text { Positive }\end{array}$ & $\begin{array}{l}\text { Not done } \\
\text { Not done } \\
\text { Not done } \\
\text { Not done }\end{array}$ & $\begin{array}{l}\text { Not done } \\
\text { Not done } \\
\text { Not done } \\
\text { Not done }\end{array}$ \\
\hline
\end{tabular}

phages containing lipofuscin are present in the same specimen. Whipple cells are scanty and mainly seen in relation to lymphoid tissue in the submucosa, but morphologically and by their staining reactions are $\stackrel{0}{\overrightarrow{0}}$ distinguishable from muciphages.

On electron microscopy the general morpho- $\overrightarrow{\vec{N}}$ logical features observed on light microscopy areconfirmed (see Fig. 1). The cell border is ill-defined $\frac{C}{\circ}$ due to protrusion of slender pseudopod-like pro- $\frac{\bar{c}}{\bar{c}}$ cesses. The vacuoles seen on light microscopy appear $\mathbb{\mathbb { D }}$ as irregularly rounded homogeneous light bodies (Figs. 2 and 3). They differ strikingly from the inclu- $s$ sions seen in Whipple's disease (Fig. 4). They range $\vec{O}$ mostly from $1 \mu$ to $4 \mu$ in diameter and are only $\vec{A}$ moderately electron-dense. Some of these bodies are outlined by a thin membrane which is well defined $\frac{\Omega}{2}$ in parts but seems deficient elsewhere. It is possible. that this represents expanded endoplasmic reticulum. 6 A striking feature of the bodies is their fragility, $\stackrel{\vec{\omega}}{\omega}$ causing artefactual retraction and fragmentation, but this may be due to preliminary glutaraldehydeo fixation.

In the specimen which showed no lipofuscin by light microscopy, occasional small, rounded, elec tron-dense particles were present, mostly at the $\vec{\oplus}$ periphery of the homogeneous light bodies (Fig. $2 \stackrel{\circ}{\circ}$ and Fig. 5).

In the specimen in which the muciphages alsoo contained lipofuscin by light microscopy there was considerably more electron-dense material aggre-o gated at the periphery of the homogeneous light $\frac{\mathrm{O}}{\varnothing}$ bodies, sometimes forming crescents or rings around ${ }^{\circ}$ them (Fig. 6). For this reason we tentatively suggest $\bar{a}$

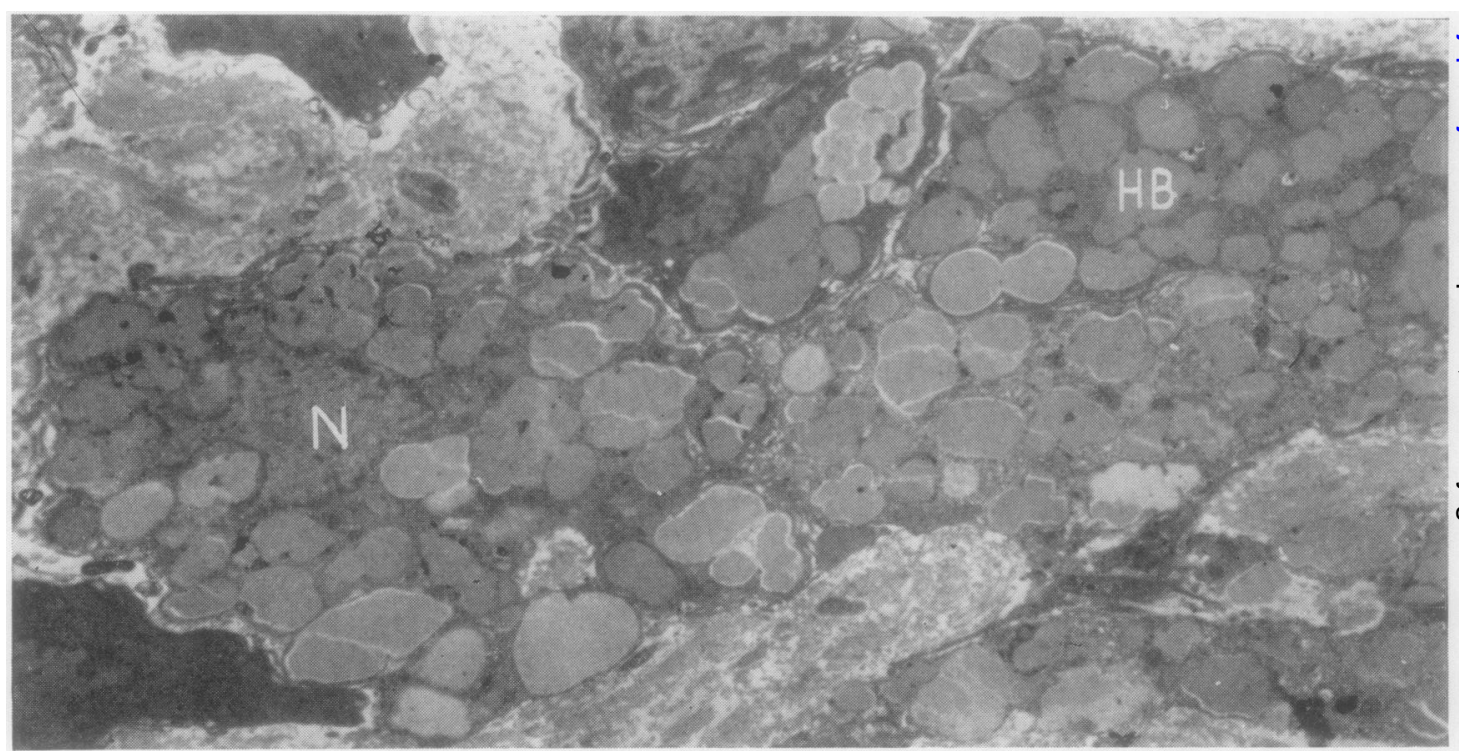

FIG. 2. At least two muciphages are present. The homogeneous light bodies $(H B)$ show artefactual retraction. Both nuclei $(N)$ are eccentric. $\times 4,666$. 


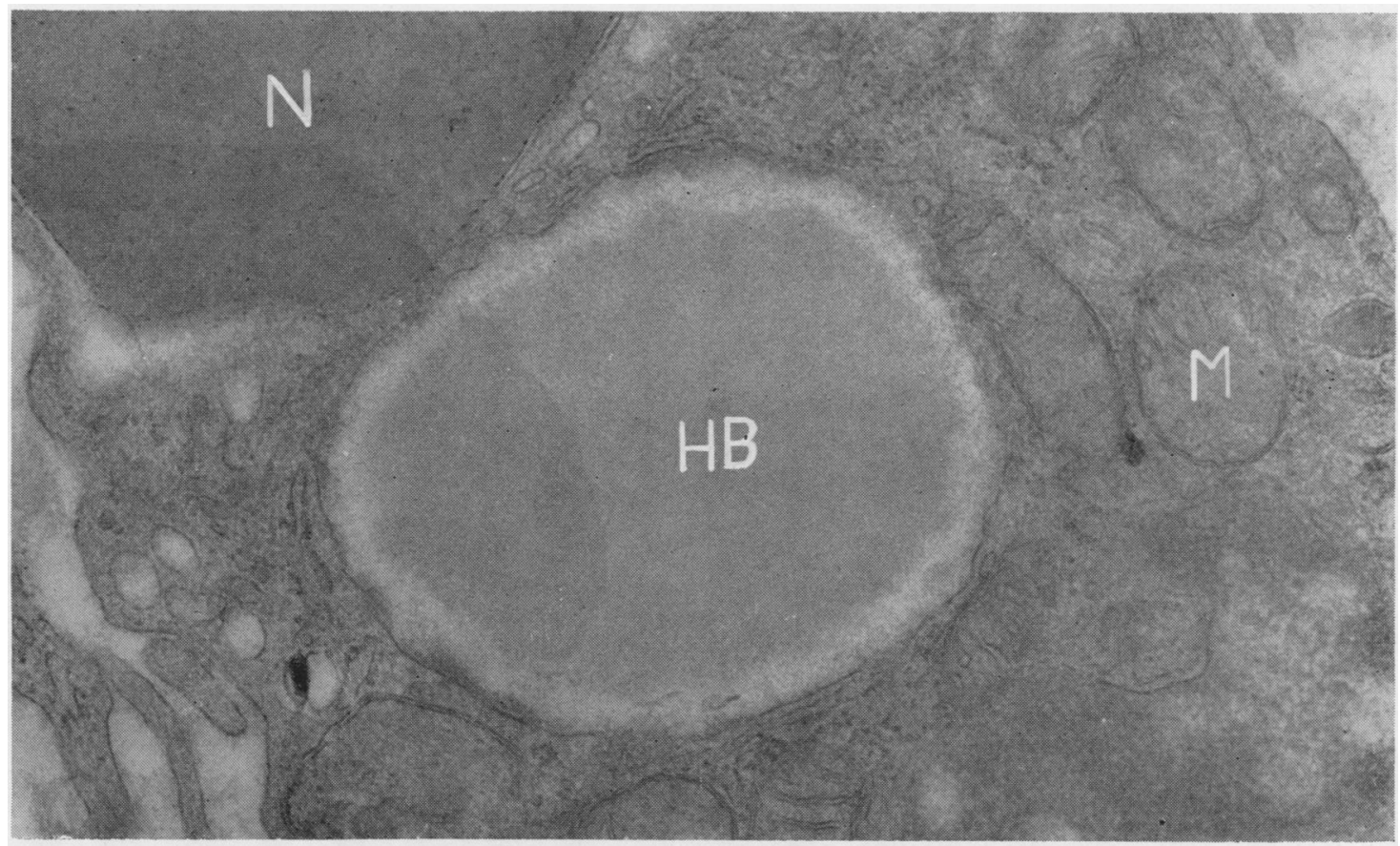

FIG. 3.

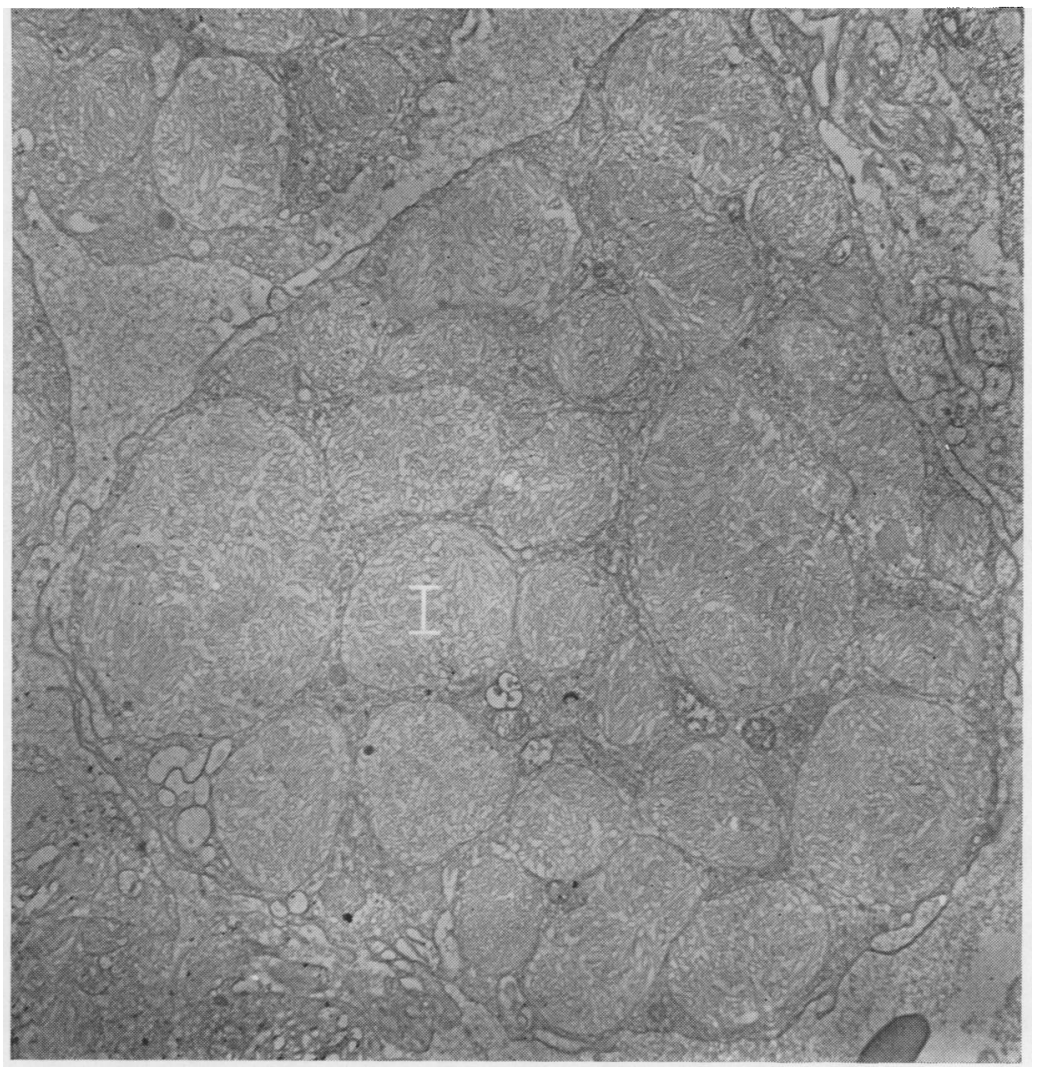

FIG. 3. The homogeneous light bodies $(H B)$ show no trace of internal structure. Mitochondria $(M)$ and nucleus $(N)$ are also present. $\times 46,666$.

FIG. 4. A macrophage of Whipple's disease. The inclusions (I) have a characteristic internal structure. $\times 7,500$.

FIG. 4. 


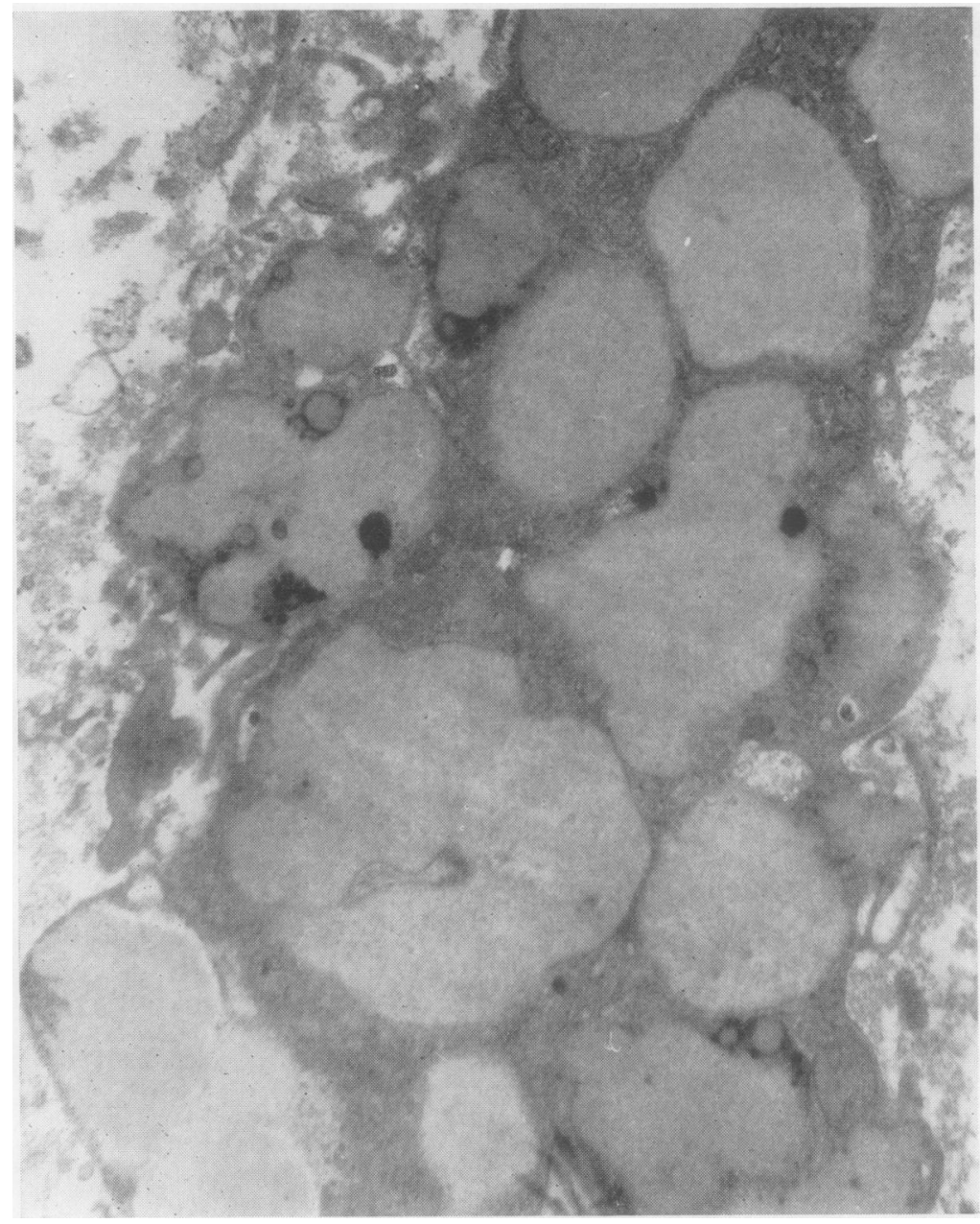

FIG. 5. Occasional small electron-dense particles are present in the muciphage mainly associated with the homogeneous light bodies. $\times 21,600$.

FIG. 6. A muciphage in which many of the homogeneous light bodies have associated electror dense material (see text) $\times 4,600$.

FIG. 5 .

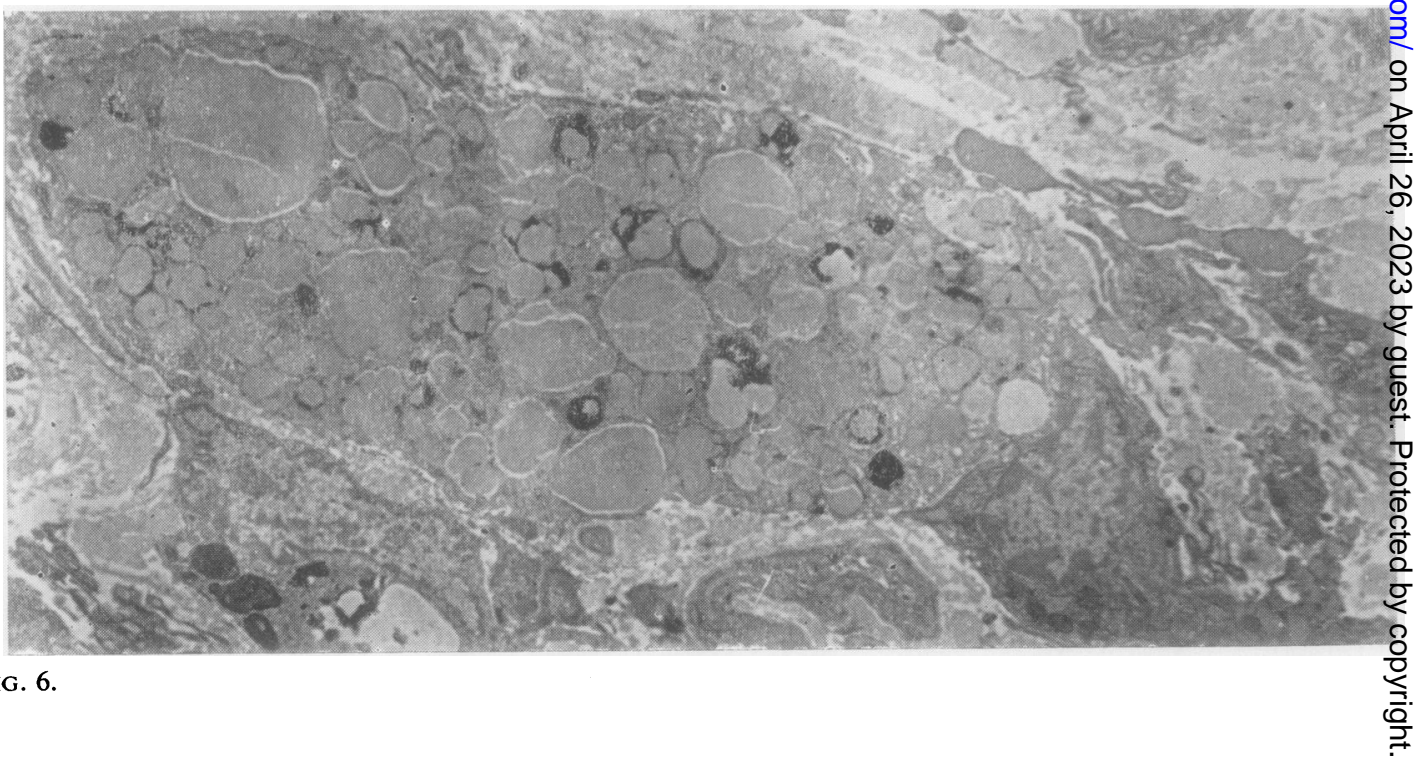


that the electron-dense material sometimes present at the periphery of the homogeneous light bodies is lipofuscin.

\section{DISCUSSION}

Fleming et al. (1962), discussing the diagnosis of Whipple's disease by rectal biopsy, stated that in routine biopsies P.A.S.-positive material is rarely found, is smudgy in appearance, diastase-labile and mucicarmine-positive. We found mucicarmine-positive cells (muciphages) frequently and their P.A.S. positivity was not diastase-labile. We agree that Whipple's disease can be diagnosed on rectal biopsy and have listed the staining reactions we found helpful in differentiating the cells from muciphages. It should be noted at this stage that there is no uniformity of opinion in the literature on the staining properties of Whipple cells. The subject is discussed by Enzinger and Helwig (1963) with whose findings we are in general agreement, though we occasionally found haemosiderin in Whipple cells.

Rowlands and Landing (1960), in examining 96 necropsies of infants and children and 28 other surgical and necropsy cases, made no comment on muciphages. In the two cases of colonic histiocytosis which they described and related to Whipple's disease, staining reactions closely resemble those seen in muciphages. In one of their cases acidfastness was reported, but in the discussion the result is referred to as basophilia and considered to be consistent with 'multiple mucopolysaccharides'. It is reasonable to assume that they are not using the term acid-fast in the conventional sense.

The relationship of muciphages to the cells described by Fisher and Hellstrom (1964) is problematical. They found cells containing ceroid-like material in one in 100 haemorrhoidectomy specimens. The identification of ceroid was based on autofluorescence, faint acid-fastness, and moderately positive oil red $\mathbf{O}$ and Sudan black reactions. Muciphages are also faintly autofluorescent and P.A.S. positive but oil red $\mathrm{O}$, Sudan black, and ZiehlNeelsen were negative and we feel therefore that there is no evidence that they contain appreciable quantities of ceroid. One important source of confusion is the coincidence of lipofuscin- and mucoprotein-containing cells in the same biopsy, a not unexpected finding considering the frequency of these cell types in the rectum. Indeed in some instances, including one specimen subjected to electron microscopy, mucoprotein and lipofuscin were seen in the same cell.

Hamperl (1950) and Sobel and Churg (1964) have discussed another group of lesions, the "histiocytic reactive lesions', which merit consideration here.
These were described as nodular accumulations of granular cells usually related to the smooth muscle of the gastrointestinal tract but occasionally found elsewhere, for example in the uterus. There was usually a history of previous surgery at the site. The cells contained coarse, rather purple, well-defined granules in preparations stained with haematoxylin and eosin and a yellow-brown pigment which was fluorescent and acid-fast. Iron and foreign material were often present in addition in the vicinity. The granules stained positively with P.A.S. and with Alcian blue, and this was interpreted as indicating the presence of an acid mucopolysaccharide. From the site of the lesion, epithelial mucin is an unlikely source of the mucopolysaccharide and an origin in damaged connective tissue seems possible. At any rate they are clearly distinct from muciphages and, in view of their localization, not likely to give rise to problems in differential diagnosis.

The derivation of the mucoprotein of the muciphages is speculative: an origin from connective tissue and synthesis by the cells themselves must be considered, but in view of the close similarity of the staining reactions of muciphages and rectal epithelial mucin, phagocytosis of the latter is an obvious possibility. The fate of the muciphages is equally obscure. The absence of a progressive increase of incidence with age argues in favour of turnover but we did not recognize stages in breakdown as indicated by variation in histochemical reactions. McCarthy, Reid, and Gibbons (1964) found that when mucin was instilled into the trachea of an experimental animal it was rapidly phagocytosed but, although the P.A.S. stain remained positive for three weeks, other mucin stains rapidly became negative. The cells also accumulated iron. We do not know if epithelial mucins released into connective tissue and phagocytosed behave similarly, but rectal muciphages have a uniform affinity for mucin stains and we did not find iron in them.

We have established that about half of all rectal biopsy specimens contain cells in the mucosa which, by light and electron microscopy and their histochemistry, have all the characteristics of phagocytes containing mucoprotein. We propose to call these cells muciphages. Although it is often possible to identify these cells in preparations stained with haematoxylin and eosin they can be distinguished most readily from the cells of Whipple's disease by the use of mucicarmine (see Figs. 7 and 8), Alcian green, and Gomori's aldehyde fuchsin. Metachromatic staining is also a differentiating point though technical difficulties (such as variations in fixation) may give rise to conflicting results. Electron microscopy shows clear differences between muciphages and the cells of Whipple's disease, confirming 


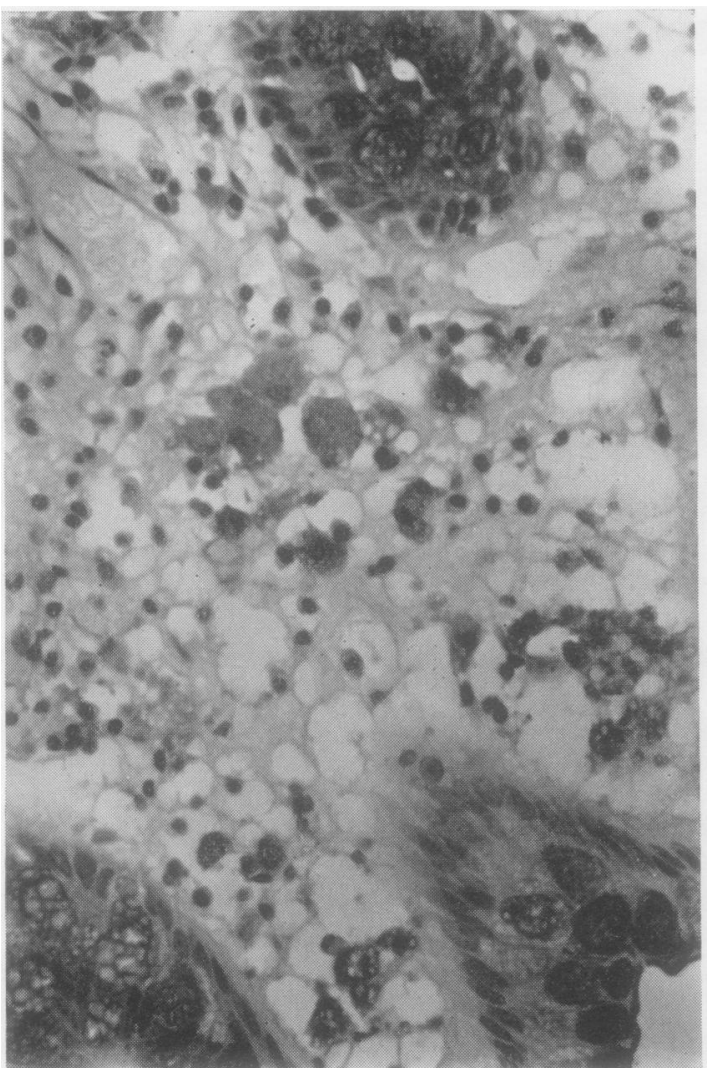

FIG. 7.

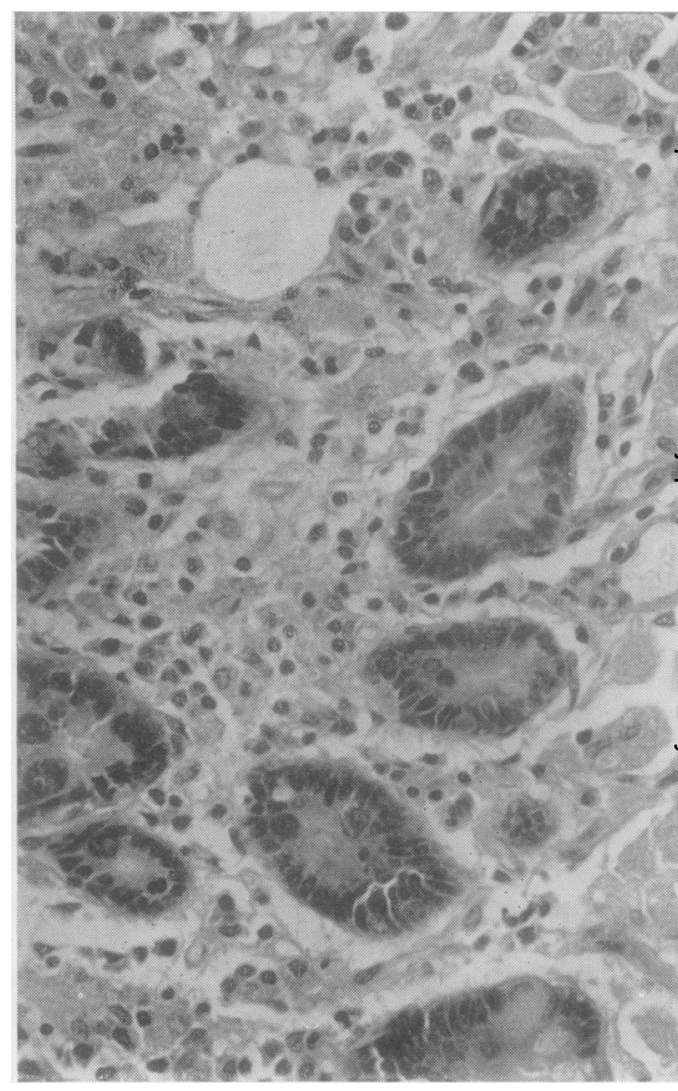

FIG. 8.

FIG. 7. Rectal biopsy with muciphages which are strongly stained by mucicarmine. Mucicarmine $\times 370$.

FIG. 8. Jejunal biopsy from a case of Whipple's disease. The macrophages are virtually unstained. Mucicarmine $\times 376$.

the findings of light microscopy. This distinction is of importance, especially since rectal biopsy has been recommended as a means of diagnosing Whipple's disease (Fleming et al., 1962).

We wish to thank Professors C. V. Harrison, A. G. E. Pearse, and R. C. Curran for helpful discussion and the last for Figure 3. We are indebted to Mr. C. Healey for the histological preparations, Mr. J. Bancroft for the enzyme studies, Mr. R. Nunn for the electron microscope preparations, and Mr. W. Brackenbury and Miss S. Lee for photographs and secretarial services.

\section{REFERENCES}

Arapakis, G., and Tribe, C. R. (1963). Ann. rheum. Dis., 22, 256. Enzinger, F. M., and Helwig, E. B. (1963). Virchows Arch. path. Anat, 336, 238.

Fisher, E. R., and Hellstrom, H. R. (1964). Amer. J. clin. Path., 581.

Fleming, W. H., Yardley, J. H., and Hendrix, T. R. (1962). New Engt: J. Med., 267, 33.

Hamperl, H. (1950). Virchows Arch. path. Anat., 318, 32.

Hourihane, D. O'B. (1966). In Recent Advances in Pathology, edited by C. V. Harrison, 8th ed. Churchill, London. In the press.

McCarthy, C., Reid, L., and Gibbons, R. A. (1964). J. Path. Bacts 87, 39.

Pearse, A. G. E.(1960). Histochemistry: Theoretical and Applied, 20 ed., fig. 208. Churchill, London.

Rowlands, D. T., Jr., and Landing, B. H. (1960). Amer. J. Path., 201.

Sobel, H. J., and Churg, J. (1964). Arch. Path., 77, 132. 